\title{
SPECIALLY PROTECTED AREAS OF THE KALININGRAD REGION: CONTINUITY OR A NEW BEGINNING
}

\author{
Andrey V. LEVCHENKOV* \\ Immanuel Kant Baltic Federal University, Institute of Environmental Management, Spatial \\ Development and Town Planning, Department of Urban Planning, Land Management and Design, \\ 14A Alexander-Nevsky Street, 236041, Kaliningrad, Russia, e-mail: ALevchenkov@kantiana.ru \\ Yuliya N. GRISHANOVA \\ Immanuel Kant Baltic Federal University, Institute of Living Systems, Laboratory of Ecology and Biodiversity, \\ 14A Alexander-Nevsky Street, 236041, Kaliningrad, Russia, e-mail: IGrishanova@kantiana.ru
}

Citation: Levchenkov, A.V. \& Grishanova, N.Y. (2020). SPECIALLY PROTECTED AREAS OF THE KALININGRAD REGION: CONTINUITY OR A NEW BEGINNING. GeoJournal of Tourism and Geosites, 28(1), 332-348. https://doi.org/10.30892/gtg.28126-473

\begin{abstract}
The paper analyses the formation of Specially Protected Areas (SPAs) in the south-east of the Baltic region within the borders of modern Kaliningrad region over the last century. The purpose was to update the look at the continuity in the field of environmental conservation. The study draws on previously unpublished post-war archive data and on the evidence of recent changes in the SPA system of the region. To investigate the continuity of environmental activities in the area, original German sources on the key SPAs of East Prussia and the reasons for their formation were analysed.
\end{abstract}

Key words: Specially Protected Areas (SPAs), Kaliningrad region, East Prussia, natural monuments, environmental conservation

\section{INTRODUCTION}

The history of environmental activities on the territory of the present-day Kaliningrad region is among the least researched issues of regional studies. Russian sources provide scarce information on the history and specifics of the formation of protected natural areas in the pre-war period. Only a few natural objects, such as ZehlauBruch (Zehlau raised bog), and Rominten Forest surface in research (Schwill et al., 2010). It was not until the 1990 s that scientific community and public initiative groups began to show more attention to this issue (Gubareva, 1994; Grishanov, 1998; Kuchenyova, 1998). Nonetheless, the Soviet period of environmental conservation of the region is usually poorly documented, with inconsistent dates of SPAs formation mentioned in various sources. For example, according to different sources, the formation of the first four SPAs date back to 1963, 1967, and 1973 (Tsybin, 2004; Volkova et al.,

\footnotetext{
* Corresponding author
} 
Specially Protected Areas of the Kaliningrad Region: Continuity or a New Beginning

2017). Among the current publications on this topic a series on natural monuments should be mentioned (Medvedev, 2016, 2017). Meanwhile, it is crucially important to find out to what extent modern environmental conservation inherits from the pre-war tradition, or whether it was methodologically and culturally formed from grassroot. We believe that this disputable issue deserves thorough analysis.

\section{RESEARCH METHODS AND MATERIALS}

The reconstruction and analysis of environmental conservation tools, their formation and development in the south-east of the Baltic region are of undoubted interest. To solve this task, we used the methodology of analysing available - primarily German - sources; we also resorted to post-war archival materials. The primary sources dating back to the period of implementation of environmental activities in the Kaliningrad region were not much in academic circulation, except for secondary literature (Lohmeyer, 1961; Kramer, 1990). Moreover, studies were primarily focused on just two aspects - SPA emergence time and their characteristics, while the internal logic of decision making and compliance with national environmental development processes remained outside the scope of research. Another aspect of the study was continuity of environmental activities, with the questions whether the development of the institution of protected areas was synchronous in the pre- and post-war period and in what directions it developed (often multi-vectorally). To eliminate the terminological confusion, the authors used the term Protected Areas (PAs) for the pre-war period (direct translation of Naturschutzgebiet). The term Specially Protected Areas (SPAs) was used in relation to the Soviet and present-time periods of environmental conservation history in the southeast of the region (according to the Federal Law of the Russian Federation No. 33-FL).

\section{RESULTS AND DISCUSSION \\ 1. THE PRE-WAR PERIOD: THE BEGINNING OF ENVIRONMENTAL CONSERVATION}

The idea of protecting natural objects at the state level in the German states originates from the movement for protection of historical and cultural monuments. At the end of the 19th century there was a consensus of all stakeholders (state and municipal bodies, public and private persons) which gave impetus to the formation of relevant institutions. The legislative basis for natural monuments protection in Prussia was set up by the decree of 19.11.1891, which delegated some authority and responsibilities in this area to the provinces. Aiming to work out general conceptual principles for that matter, the provincial president of East Prussia Count Udo zu Stolberg-Wernigerode (1840-1910) organized a conference in Koenigsberg on November 17,1892 . The plenary report was made by Reinhold Persius (1835-1912), an invited (state) monument conservator from Berlin. As a result of the conference, the provincial parliament formed the Commission for the Study and Protection of Monuments in the Province of East Prussia on March 11, 1989. The commission included 13 members, as well as representatives of the scientific community.

The objectives were as follows: to awaken people's awareness of the significance of natural monuments and to involve people from all walks of life in monuments' preservation, maintenance and rehabilitation (Boetticher, 1898). On the $16^{\text {th }}$ of December, the commission began its work by choosing the executive board and experts from its members. The architect Adolf Boetticher (1841-1901) known for his work on the programme of photographing monuments of East Prussia (Przypkowski \& Jamski, 2005) was elected provincial conservator. Unlike in other countries, in Germany a provincial conservator was not appointed but elected, usually for a term of five years. 


\section{“THE LIST..." OF ALFRED JENTZSCH}

The commission also included a 43-year-old geologist, Alfred Jentzsch (18501925), who was director of the East Prussian Provincial Museum of the Association of Physics and Economics. Three categories were chosen for the selection of potential conservation objects: intact natural landscapes - in the face of ever-increasing involvement of land in the economic turnover (in East Prussia land area occupied by agricultural use due to deforestation, land improvement and drainage of wetlands increased to $68.17 \%$ or 2515989 ha (Bloech, 1980), also for the preservation of wetlands diversity; trees of considerable size and age, and geological objects. Based on these prerequisites, A. Jentzsch filed an application to the commission in March 1896 requesting that "... besides monuments and antiquities in the narrow sense of the word, conservation objects should include certain natural formations, distinguished by their age or special features" (Jentzsch, 1900, p. 7). The Commission approved the application and asked him to develop a questionnaire whose results had to be prepared for publication no later than 1898. Stamped by the head of the provincial government, the printed questionnaires were circulated only in April 1897. As is often the case, the author did not meet the prescribed deadline, and the work extended until the autumn of 1900.

"The List ..." Of Alfred Jentzsch is structured according to the alphabetical index of settlements of respective administrative-territorial units. The location of the natural object, its name and the name of the applicant were all sequentially indicated- for example, an over-600-year-old oak tree (Quercus pedunculata) in the manor park in Neuhausen (Guryevsk) or the savin juniper (Juniperus sabina) growing in Nordenburg (Krylovo). The second part of "The List ..." contains brief descriptions of individual species of trees and shrubs (the most prominent items were provided with drawings). The description of the exact location of objects is of particular interest. For example, it is reported that in 1872 prof. Caspary measured the linden that grows north of the church in the cemetery of Muehlhausen (Gvardeyskoye). At a height of three feet from the ground, its circumference was $4.87 \mathrm{~m}$, the size of the crown measured 19 steps and its height was approximately $22.00 \mathrm{~m}$. The tree was estimated to be 400 years old. The third chapter was devoted to the location of noteworthy boulders. Being a geologist (in 1878 Jentzsch participated in the preparation and publication of the Geological map of East Prussia on the scale of 1:100 ooo), the author studied this topic in the utmost detail, as we believe.

As an example, a boulder of Breitenstein (Ilyushino) can be mentioned, its outstanding size was as follows: length $-4.80 \mathrm{~m}$; width $-3.50 \mathrm{~m}$; height above ground level $-0.45 \mathrm{~m}$; circumference $-15.00 \mathrm{~m}$. One can only wonder at the amount of work the author of "The List ..." had to do, given the huge number of questionnaires sent. The publication turned out to be less academic than educational and focused on local history. Further activities required more detailed and painstaking work done by a more numerous team rather than an enthusiastic individual and, most importantly, the presence of a permanent state environmental authority. Initial features of the application, the content of the questionnaire, the lack of time, a large number and heterogeneity of correspondents hindered a detailed description and assessment of all the proposed objects. Despite the fact that some objects were described in detail, many were listed as 'vacant' ones, i.e. requiring additional study. Nevertheless, the importance of this list is indisputable, since it was the first contribution of this kind to environmental activities in Germany.

\section{STATE INITIATIVE}

In 1898, the Prussian Ministry of Religious, Educational and Medical Affairs commissioned Hugo Conwentz (1855-1922), the director of the West Prussian Provincial Museum in Danzig (Gdansk), to prepare an expert note concerning the state of affairs in 
natural objects conservation. In 1904, the document was prepared and handed over to the ministry (Conwentz, 1904). Analyzing this document, even the contemporary fellow experts noticed the author's one-sided and irrational position regarding environmental conservation. Thus, assuming that the Ministry of Finance would resist the move, Conwentz proposed creating and supporting communal unions, public associations and private initiatives, which would not require funding from the state. To coordinate public and private environmental initiatives, he proposed to set up a public institution.

In 1906, Conwentz was given the authority to establish the State Commission for the Protection of Natural Monuments, which would enable and oblige the state to collaborate with municipalities, institutions and public associations. Officially, the Commission took office in Berlin only in 1910. Thus, it was in Prussia that nature conservation formally reached the state level for the first time; however, it did not mean that nature conservationists automatically received any preferences. On the contrary, in 1912 the draft law on natural monuments protection did not win a majority in the Prussian parliament- which was a logical consequence as conservative deputies resisted the expansion of conservation activities on private property. Another body for improving the efficiency of nature conservation was the public "provincial committees".

Representatives of relevant institutions and associations, academic bodies, or just concerned individuals could become members of provincial committees. Day-to day work was carried out by the board called, since 1924, "The Commissars".

3. THE FIRST PROTECTED AREAS OF EAST PRUSSIA (within the borders of the modern Kaliningrad region territory)

By the beginning of the 2oth century, comprehensive protection of the entire landscape, rather than its individual parts, became the predominant concept of nature conservation in Germany. The first protected areas of this kind in East Prussia included Zehlau raised bog, Chaika Lake on the Curonian Spit, and the Galtgarben and moraine.

\subsection{Zehlaubruch raised bog}

In early 1909, the Geological Land Service filed a request to the Prussian government to preserve a marsh in East Prussia. On the 6th of April 1909, the Prussian Minister of Agriculture, State Property and Forests gave his agreement in principle. A well-known paleo-botanist Professor Henry Potonié (1857-1913) was invited to study relevant marshes and he singled out Zehlau as particularly remarkable. Another active supporter of the protection status assignment was Carl A. Weber (1856-1931), who was a botanist at the Prussian experimental swamp station in Bremen in 1894-1924. On the 10th of March 1910, the mash was subsequently declared protected natural area. At that time, it was the largest protected area (2 360 ha) in Germany. Why was Zehlau chosen to become the first SPA in East Prussia while there were other equally remarkable swamps? In our opinion, a combination of factors was of crucial importance here. Firstly, it remained an intact mash in its original state despite the cultivation plans which had existed since the 18th century. The first geodetic survey was carried out in 1826 followed in 1841-42 by a more accurate one with the levelling and tracing of probable drainage ditches. In the 1860s, the Forestry department made an attempt to drain the northwestern section of Zehlau, but faced considerable difficulties and abandoned the project. Secondly, a specific element of the surrounding landscape and part of the glacial landscape, Zehlau was located in the valley of the river Pregel on the outskirts of a large forest range Gauleden (Ozersky forest), l most of the province's marshes.

At the time of obtaining the protected status, Zehlau-Bruch had hardly undergone a comprehensive scientific study. If Jentzsch had paid more attention in his work to the typology of mashes, their morphology and chemical composition, the tax inspector 
Stiemer would have approached the issue of studying the existing mashes in the province from a purely utilitarian point of view (Stiemer, 1875). Apart from the above-mentioned works by Stiemer and A. Jentzsch, the first specialized research of the geology and flora of the mash was conducted by Hugo Gross (1888-1968). Gross is a pioneer researcher in (paleo) botany, geology, and dendrology of East Prussia. But the significance of his "Botanical Forest Reference Guide on East Prussia" as a list of natural monuments is not entirely clear to the authors, although W. Wagner refers to it saying that the status of natural monuments was obtained by the outstanding trees in 1935/38 (Wagner, 2009). A systematic study of the mash as an environmental object was interrupted by the First World, so the monograph was released only in 1929 (Gams \& Ruoff, 1929) In addition to its uniqueness as a growing raised bog, Zehlau attracted the attention of ornithologists as a nesting ground for the crane and the Ural owl in the forest adjacent to the bog.

\subsection{Lake Chaika (Moewenbruch)}

Lake Chaika (Moewenbruch) by the village Rossitten on the Curonian Spit has an area of approximately 30 ha and owes its status primarily to Prof. Johannes Thinemann (1863-1938), the director of the Rossitten ornithological station. He repeatedly applied to the government with a proposal to grant the lake the status of a bird sanctuary. In January 1906, his next application to the head of the Koenigsberg government was supported by the Association for the Natural Monuments Protection in East Prussia. Only then the state agreed to "allow there ornithological research and, if possible, leave the lake in an intact state" (Article to the conservation of natural monuments, 1926). The explanatory note states that the banks covered with club-rush and reeds are the nesting site for numerous bird species, such as the Black-headed gull, the Common tern, the Reed bunting, the Great crested grebe, the Marsh warbler, and others. With the formation of the Curonian Spit as the federal-level natural protected area on December 6, 1940, the lake became part of it, but due to special legislative acts it had a higher protective status and was supervised by the ornithological station (Article to the conservation of natural monuments, 1926).

\subsection{Mount Galtgarben}

At the same time, a public commission submitted a proposal to the district council of Fischhausen concerning the end moraine landscape with the Galtgarben elevation, which stated that there was "a need to preserve the natural monument of particular beauty and originality, and to prevent it from getting into the hands of speculators sooner or later" (Article to the conservation of natural monuments, 1926). In this case, however, it was primarily a matter of historical and cultural significance of the landscape rather than of the natural object itself. Besides the natural object comprising a mixed coniferous forest with peat bogs and endorheic basins, the territory of the monument also included historical objects: an iron cross (1818) in memory of the East Prussian Landwehr participation in the war against Napoleon in 1813-15; a tenmeter high observation deck (1894), and the Bismarck Tower (1906). Among the prehistoric monuments there was the Prussian fortress "castrum Rinow" - a circular shaft fortification mentioned in 1278. Even before the final decision on the purchase, the head of the district government declared Galtgarben protected area on February 27, 1908. The decision based on the law of 15 July 1907 on the prohibition of changing the territory through construction development. The issue of environmental protection became particularly relevant in a new political climate after the end of the First World War: Art. 150 of the Basic Law of Germany placed natural monuments under state protection. The institute of Commissars for the Protection of Natural Monuments was formed (In 1922 Prussia had 12 land and 10 district commissions having 12 provinces divided into 37 governmental counties). The efforts of conservationists were mainly focused on developing a unified law on nature conservation. In the 1920s, Prussia was 
hardly the epitome of environmental activities among German states. In 1931, with its 300-state environmental institutions of various levels, Prussia was lagging far behind Wuerttemberg - among other cities - where commissions had existed since 1911 in all 64 oberamts (comparable to Prussian districts) (Wettengel, 1993).

\subsection{Samland coastal grove}

The so-called Samland coastal grove with the area of approximately 2800 ha became the fourth protected area in East Prussia. The status was granted by the resolution of 28.06.1934 (Newsletter for nature conservation, 1934) stating that the boundary of the nature reserve lies at a distance of approximately $100 \mathrm{~m}$ from the coast (from Pillau to Cranz) and includes adjacent gorges and forests. Rules of conduct in a protected area are comparable to the modern order prevalent in national parks: walking only on specified roads, ban on the destruction of vegetation, hunting, making fire, driving and walking along the coastal slope and foredunes etc. This protected area should be considered, first of all, in terms of protection measures on the steep coast of the Sambian Peninsula, but not as a complex, valuable or unique landscape. In 1911, the Coastal Municipalities established the Samland Coastal Protection Union whose main goal was to awaken public interest to the preservation of the crumbling Sambian coast, as well as fundraising for the construction and maintenance of shore protection structures (groynes, walls etc.). After World War I the Union developed a project to protect the coast. It aimed at the expansion of the beach and the protection of the steep coast foot. At the first stage it was planned to build 60 groynes and take care of the foredune. Construction of the groynes began in 1926 in the northern section of the coast (Brückmann, 1923; Levchenkov \& Ryabkova, 2012). Therefore, the protection status granted to the coastal strip of the peninsula should be considered in this perspective.

The long-awaited Law on Nature Protection was adopted on 06.26.1935. For the first time, the law established common nature protection regulations at the federal level for the whole territory of the country. The term "nature conservation" was significantly extended by the concepts "landscape appearance protection" and "protection of landscape parts". Since April 1, 1936, the Imperial Commission for Nature Conservation became a supreme environmental authority subordinate to the Imperial Forestry Agency. The commission was tasked, among other things, with studying natural monuments and SPAs, providing consulting and expert services (as the highest environmental authority), bird ringing control, and listing and delisting of protected objects. Following the legislative framework initiated by the Law on Nature Protection of 1935, all protected objects could be divided into three types. Territories with federal status reached a new level and enjoyed the highest status. As of January 1, 1943, eight such SPAs (out of 21 in the entire province) were located within the today's borders of the Kaliningrad region (Lohmeyer, 1961); there were 55 protected areas of higher and approximately 880 of lower level (1938) throughout Germany (Wettengel, 1993).

Next were provincial (regional) and local levels, which included, as a rule, remarkable small landscapes and natural monuments. Taking into account that natural conservation activity was part of the forestry authority, it is not surprising that the long-standing hunting grounds, Rominten Forest and German Elk Forest became the first new federal protected areas in 1937. Two pre-existing SPAs confirmed their status; they were Galtgarben with an area of 33.82 ha (Resolution of 09.30.1939) and the Zehlau raised bog with an area of 518.79 ha (Resolution of 3.2.1940). The Rominten Forest protected area amounted to 22170 ha of virgin coniferous and deciduous forest, as well as swampy meadows. It was an area of exceptional scenic beauty, also highly rich in rare species of flora and fauna (the Black Stork Ciconia nigra, the Elk Alces alces, the Red Deer Cervus elaphus, the Raven Corvus corax). The raised bog at Nassawen (Lesistoye) was of particular 
interest as the place of raised bog plants and the swamp spruce forest around Sodwarier See. The so-called German elk forest occupied a special position in the nature conservation system in East Prussia (12.9.1937, area 46550 ha). The reserve became a special forest management area comprising 11 forests joined by Rossitten and Schwarzort forests on the Curonian spit in 1939 and by Leipen and Grauden in 1941 (Table 1).

Table 1. Forestry of protected area German Elk Forest

\begin{tabular}{|c|l|c|c|}
\hline & \multicolumn{1}{|c|}{ Forestry } & Total area, ha & Area, covered by forest, ha \\
\hline 1. & Pfeil & 6622 & 4963 \\
\hline 2 & Klein Naujock=Erlenwald & 4830 & 4066 \\
\hline 3. & Tawellningken=Tawellenbruch & 11511 & 9084 \\
\hline 4. & Ibenhorst & 6521 & 5264 \\
\hline 5. & Rossitten & 10187 & 8869 \\
\hline 6. & Gertlaucken & 4589 & 3767 \\
\hline 7. & Alt-Sternberg & 7113 & 6725 \\
\hline 8. & Neu-Sternberg & 5644 & 4826 \\
\hline 9. & Drusken & 4968 & 4411 \\
\hline 10. & Leipen & 4833 & 4364 \\
\hline 11. & Papuschienen/Grauden & 7294 & 5076 \\
\hline & Total & $\mathbf{7 4 1 1 2}$ & $\mathbf{6 1 4 1 5}$ \\
\hline
\end{tabular}

In 1938, Hans Kramer (1896-1982) was appointed as Director of the Forestry and Reserve Area. The main task, as the name of the forest suggests, was to preserve the only Elk population in Germany in its natural environment. In July 1941, Elk Forest was removed from the provincial control and became subordinated to the Federal Forest and Hunting Agency. With its total area of more than 100 ooo ha (75 000 state and 25000 leased forests), the nature reserve was almost a single woodland of mixed and vast alder forests with a high diversity of fauna species (the Common Crane Grus grus, the Owl Bubo bubo, the Small Spotted Eagle Aquila pomarina and the Great Spotted Eagle Aquila clanga). If, in terms of their size, Rominten Forest and Elk Forest were not national parks in the modern sense of the term, they definitely were their predecessors. Basically, they were personal hunting grounds of the "main hunter" of Nazi Germany, and in 1941 they received the status of "state hunting grounds". No special authorities of federal significance existed for protected areas at that time - nothing similar to the present-day Curonian Spit National Park. Large objects were taken care of by the relevant authorities on their grounds. The owners were obliged to look after individual monuments if the latter were located on their sites. Since 1934, the general management of environmental activities at the level of government districts and on sites was carried out by the institute of nature conservation officials. In the early 1940s, the Curonian Spit received protected status, the process having lasted for nearly 18 moths. First, the southern part of the spit was granted the status (Resolution of 6.12.1940, area 4769 ha), and then its northern part, which previously (1923-39) belonged to Lithuania (Resolution of 9.5.1942, area approximately 8700 ha). The rationale behind the decision included typical sea beaches, unique landscape of moving dunes, richness in species and in number of avifauna of the sea and shoals were provided as a ground. In addition, it was noted that the spit is the easternmost habitat of such dune plants as the Goatsbeard Tragopogon floccosus and the Sweet-scented Toadflax Linaria odora. In 1928, a section of the Curonian Spit from the Lithuanian border (point $50.8 \mathrm{~km}$ ) to the forest part at $55 \mathrm{~km}$ (the spit's distance was counted from its northern extremity) was declared protected area according to Otto Jessen (1891-1951), Professor of the Rostock University (Jessen, 1937). Vehicles was prohibited (allowed only in exceptional cases on official business), with only cartage allowed for local 
residents. Forestry lands were a protected territory of the spit (at least until December 1940). The constant maintenance of the foredune and the part of heather up to the post road was the responsibility of Rossitten's dune caretaker, who was directly subordinate to the Water Construction Administration in Labiau and the head Directorate in Koenigsberg. The caretaker had 10 workers at his disposal to carry out repair work.

The opinion of the aforementioned Conwentz about dune reinforcement is worth quoting: "Thanks to planting and afforestation, a complete change has occurred in the dunes and their flora and fauna in the coastal areas of the North and Baltic seas. In 1900,8120 ha of particularly typical moving dunes of the Curonian Spit reaching at places a height of $70 \mathrm{~m}$ were fixed and lined with forests, while 5150 ha still remained mobile. In addition, the spit was equipped with an artificial protective dune preventing the formation of new moving dunes almost along its entire length. Only between Rossitten and Sarkau there still remained an untouched 3km-long stretch, but when restrictive works started there too, the original nature monument ceased to exist" (Conwentz, 1904, p.9). We could not find an unequivocal answer regarding the rule of conduct on loose dunes before and after the protection status. However, the analysis of the available sources leads to the conclusion that dune landscapes had not enjoyed protection status at least until December 1940. In 1937, a small Bredshuller raised bog (or Elchwinkler bog) with an area of 3 ha was added to the list of the PAs of regional importance. It was granted protection status not so much as a unique object but as the conservation area for the elk Alces alces and the gray crane Grus grus.

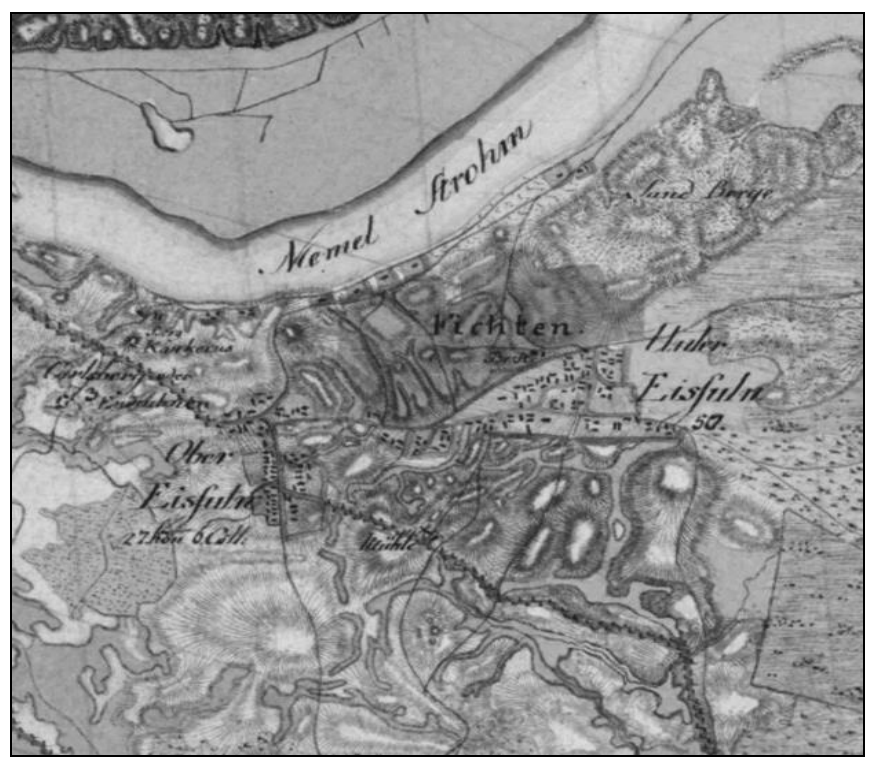

Figure 1. Continental Dunes (Schroetter \& von, Jaeck, 1978)

A special type of protected objects is represented by geological monuments, such as the gorges of the Katzenbach and Trakis creeks, and also the continental dunes of Unter-Eisseln. The area called Katzengruende is indicated "as the territory of special landscape importance” (Newsletter for nature conservation, 1934). It represented a gorge with the stream of Svetlogorka (Katzenbach) running from the current Svetlogorsk-1 and Grachevka (Craam) village. A similar Trakis Creek Gorge (Resolution of 8.3.1938) with an area of 42,78 ha was a woodland of small-leaved lime mixed with 200-year-old oaks. 
The gorges at the northern edge of the present-day Chernyakhovsky forest was 12-15 m deep. High diversity of ferns was noted. The bed of the stream had erratic boulders.

The Continental Dunes of Unter-Eisseln (Resolution of 14.5.1938) with an area of 86.5 ha is located south of Bolshoye Selo (Figure 1).

They are relict formations related by origin to the great delta of the great-Neman river. It was believed that this eastern-most habitat of some plants makes it possible to explore the natural course of inland dune consolidation.

In his list named "Protected Territories of the German East" (Lohmeyer, 1961) additionally mentions three objects whose status has not been confirmed in spite of meticulous search (other authors found nine protected areas, which were marked by $\mathrm{H}$. Lohmeyer excluding the Bredshuller raised bog, and both parts of the Curonian Spit were included in the "Elk Forest" (Medvedev, 2017). These are Bolshoye Mokhovoye Marsh in the Neman delta, Verkhovoye swamp of Nemonin at the Curonian Lagoon and the whole delta of the Neman. The latter object as a protected area seems unlikely.

A special place in the environmental activities of East Prussia was occupied by ornithological conservation areas, which, however, often coincided with the existing official protected areas. Having no legal status, they nevertheless played an important role. Among those planned for protection, the following should be named:

1. Mupiau raised bog (the Big Bushes tract in the former Kamensky reserve (meaning the reserve that existed in 1963-2004) in Grauden Forestry, which was about 1.700 ha, including marginal forest areas. The nesting place of the Crane Grus grus, the Small Spotted Eagle Aquila pomarina, and the Black Stork Ciconia nigra.

2. Protective bulk islands of the Koenigsberg Canal. The nesting site of the Common Tern Sterna hirundo, the Small Tern Sterna albifrons and the Common Ringed Plover Charadrius hiaticula.

3. Ponds of the Koenigsberg water supply system in Samland.

4. Water meadows of the Pregel's mouth. The nesting place of the Dunlin Calidris alpina, the Black-tailed Godwit Limosa limosa, the Common Redshank Tringa totanus Linnaeus and the Ruff Philomachus pugnax.

Thus, the territory of the modern Kaliningrad region and the pre-war environmental system included fifteen (out of 47 in the whole province) specially protected objects:

1. Typical hunting sanctuaries, which were directly subordinated to the hunting agency: Elk forest (together with both parts of the Curonian Spit) and Rominten Forest. They were habitats of the Elk Alces alces and included almost all state forests.

2. Landscapes of raised bogs (Zehlaubruch, Bredshuller, Bolshoye Mokhovoye Marsh).

3. Geological (Trakis and Katzengruende gorges) and geomorphological objects (Galtgarben, the Samland peninsula coast, the relic dunes of Unter-Eisseln).

4. Ornithological objects (Lake Chaika) (Lohmeyer, 1961).

5. Monuments of nature including 272 objects (Jentzsch, 1900).

The composition and the scope of the protected areas in East Prussia fully reflect the specificity of this natural region.

\section{POST-WAR PERIOD}

In the first years of the newly formed Koenigsberg (Kaliningrad) region, the issue of natural conservation was not a priority compared to the problems of economic recovery. However, it does not mean that no attention was paid to the issue. At the beginning of 1946 (Order No. 66-p from 16.01.1946 of the Council of People's Commissars of the RSFSR (Russian Soviet Federative Socialist Republic), laws and regulations on hunting reserves enforced for the RSFSR were extended to the territory of the Special Koenigsberg Military District. At the same time, it was requested that "... The Main Directorate for Hunting and 
the Main Directorate for Reserves at the Council of People's Commissars will send representatives to Koenigsberg in order to organize the Department of Hunting Management (hereinafter referred to as DHM) and will organize and restore the nature reserves" (State archive of the Kaliningrad Region (SAKR, Fund 380, Inventory 1, Case 3, Page 3). According to the first DHM report submitted in April 1946, there was a significant reduction in the number of hoofed and fur-bearing animals in the Kaliningrad region due to hostilities, as well as to unsupervised hunting in the first post-war year. The numbers of the Elk Alces alces, the Deer Cervus elaphus, the Fallowdeer Dama dama and the Roe Deer Capreolus capreolus were extremely low. However, with wetland fowl the story was completely different. Owing to the destruction of the reclamation system, most of the coastal areas adjacent to the bays appeared to be flooded and impassable for humans, which had had a positive effect on waterfowl population (SAKR, F. 380, Inv. 1, C. 3. P. 9-12). In July 1946, a commission arrived from the Main Directorate of Reserves to examine the former German reserves (to the authors is unknown the extent to which the General Directorate of Reserves knew about the protected areas of East Prussia) and to submit materials to the Council of Ministers regarding the organization of three State reserves (Astravishken, Rominten and Elk forest) covering a total area of 65 thousand ha (SAKR, F. 380, Inv. 1, C. 3, P. 7-8). However, those nature reserves did not happen. They were last mentioned in the 1947 DHM report stating that the Main Department for nature reserves had never answered to repeated requests to organize those protected areas in the Kaliningrad region, which delayed allotting hunting grounds, including the territory of the planned reserve, to the Military Hunting Society (SAKR, F. 380, Inv. 1. C. 8, p. 36-37). According to the authors, this was due to the state's general policy which was reoriented after the war towards developing rather than protecting nature, which resulted in the elimination of the majority of reserves in favour of the national economy (Brain, 2012; Lyubchenko \& Liverovskaya, 2014).

Naturally, it was the state's authorities that showed interest in the new RSFSR region's nature. Thus in 1949-52 the Complex Commitee from the Komarov Botanical Institute made an assessment of the region's forests, vegetation, botanical gardens, parks, etc. in order to use them in national economy. A high appraisal was, in particular, given to the diversity and richness of ornamental and introduced plants (SAKR, F. 297, Inv. 7, C. 266; P. 26; Kuchenyova, 1998). As follows from the report of DHM in 1947, hoofed animals were considered as valuable breeding material for further dissemination in the Union of Soviet Socialist Republics (SAKR, F. 380, Inv. 1. C. 8, P. 12).

A new stage of "quasi-protective" activity in the region is associated with the improvement of environmental legislation at state level, including the adoption of the first law on environmental protection of the RSFSR (1960), as well as a number of other laws and regulations aimed at preserving the country's natural resources (Makeeva, 2017). To that end, in the first half of the 1960s the Main Department of Hunting and Nature Reserves of RSFSR system forms a network of wildlife reserves with the aim to protect and reproduce hunting and commercial species. Such reserves were created for a certain period only; unlike nature sanctuaries, they were not meant for complete withdrawal of their territory from economic use (Lyubchenko \& Liverovskaya, 2014).

It was during this period that the first SPAs appeared in the Kaliningrad region. According to the Resolution of the Council of Ministers No. 569 of 05.13.1963, the executive committees of structural units of the RSFSR were ordered to establish nature reserves in especially valuable lands and to ensure that the hunting grounds were assigned to local associations of hunters and fishermen. This the first hunting nature reserves -the "Kursk Spit" (under the name the "Kursk Spit" the zoological reserve existed until August 26, 1985, since then it named the Curonian Spit"), the "Vistula 
Spit", "Maysko-Krasnopolyansky" and "Kamensky" - were created in our region (Order of the Regional Executive Committee No.582-P dated July 3, 1963). It is noteworthy that this order prohibited any hunting in the nature reserves. The Forestry Department was entrusted with supervisory and monitoring functions, and the protection of the two other nature reserves was entrusted to the National Hunter Inspection, a division of the regional executive committee. The reason for creating the fifth reserve in the region is worthy of note. In 1976, the director of the Kaliningradzveroprom Trust filed an appeal to the regional executive committee requesting to consider the ban on hunting and dog training on the territory adjacent to a deer farm within a radius of 10$15 \mathrm{~km}$. The issue was resolved positively and resulted in setting up Novoselovsky complex (!) nature reserve for a period of 10 years. It was subordinate to the state hunting inspectorate (Regional executive committee order No. 341-p dated 12.08.1976). The purpose was to protect the Sika Deer Cervus nippon livestock introduced in 1975 into the Novoselovsky reindeer antler farm. It appears to be quite obvious that the first regional nature reserves were formally created without any scientific justification; they served as hunting reserves, or, as in the latter case, as a sanitary zone for a deer farm.

Quite different factors and causes underlie in the history of natural monuments protection in the Kaliningrad region, which are described in detail in the series publication Nature of the Kaliningrad region (2013-2017) (Medvedev, 2016; 2017). One fact is worth noting: the region's scientific community played an active role in the formation of the SPAs network. In 1970-80, the All-Russian Society for the Conservation of Nature (RSCN) (Makeeva, 2017) was becoming a powerful environmental force in the country. Scientists from two leading regional universities, Kaliningrad State University and Technical Institute, became founders of the Kaliningrad RSCN. Among them, Galina Kuchenyova (1925-2007) occupies a special place. One can only guess whether the Soviet / Russian scientists were fully aware of the historical heritage in the field of nature conservation. Most likely, they were not, which became apparent from the analysis of the methodology and subject matter of the 1985 and 1900 lists of nature monuments. There is not a single correlation between 59 objects of the Decree and 568 natural monuments (albeit those of the entire territory of East Prussia).

In the 1900 List, individual objects are indicated as nature monuments, but among them there is seldom a forest, an urban forest, or a park. Meanwhile, in the List of 1985 , the majority of monuments are viewed as park complexes: urban, manor, and suchlike dendrological parks. The difference is due to a different methodological approach to the compilation. The List of 1900 was initially focused on old trees and boulders of outstanding size. The name of the questionnaire developed by A. Jentzsch was very clear: "The questionnaire on the presence of old trees, which are of special interest because of their generic type, size, unusual development or special factors" (Jentzsch, 1900, p. 4). The 1985 List, however, was aimed at protecting historical heritage. What looks like something outstanding for a contemporary - a collection of a large number of various introduces - was in fact a common practice 100-200 years ago, when each estate owner strived to enrich their park in every possible way. Erratic boulders, for example, are not represented in the modern list of monuments at all.

National parks as territories for people's organized communication with nature enjoy certain restrictions on economic activities, and they are a relatively young form of SPAs in Russia. Not before the 1980 s did he RSCN develop the principles for this category of SPAs, and since 1983 the formation of the national park system was vested in the RSFSR Ministry of Forestry. The Curonian Spit National Park was established on the territory of the Kaliningrad Region in 1987 in order to preserve unique natural complexes of the Curonian Spit and use them for educational, recreational, scientific and cultural 
purposes. The initiative to set up this national park also belongs to G. Kuchenyova who was at the time secretary of the Kaliningrad branch of the RSCN (Zueva, 2017).

Thus, by the beginning of the 1990s, a network of SPAs had been founded on the territory of the Kaliningrad region; it included one national park, four nature reserves and 61 natural monuments. The nature protection system was established in accordance with the national trends in the development of nature conservation of that time - on the one hand, it was a priority of the national economy over protection of nature (nature reserves), and on the other, an active position of initiative citizens and scientific organizations of the region (national park and nature monuments).

\section{THE 1991-2005 PERIOD}

At the federal level, the early 1990 s became almost the most favourable period for the preservation of natural heritage in Russia. In 1995, the State Duma of the Russian Federation ratified the "Convention on Biological Diversity" and passed very significant environmental laws: "On the Animal World" and "On Specially Protected Territories". The latter identified seven SPAs categories and set out their status, goals, objectives, protection regime, sources of funding, formation order, functioning, etc. The plan to create 72 new reserves and 46 national parks was approved for the period up to 2005 (Order of the Russian Federation Government of April 23, 1994 No. 572-p "On the organization of state natural reserves and national natural parks in the Russian Federation"). In compliance with the Order, it was planned to create a natural reserve "Pravdinsky" in the Kaliningrad region, which included the natural marsh complex of the Baltic Lake Plain (Zehlau raised bog) covering an area of 2.4 thousand hectares. However, this plan was not to become reality. In 2001, the order was no longer valid because a new plan had been approved to develop a smaller-scale SPAs network in Russia -nine new reserves were envisaged instead of 72; "Pravdinsky" reserve was not included for the lack of state funding (Tsybin, 2004). The creation of three complex (landscape) nature reserves ("Dyunny", "Gromovsky", "Vishtynetsky") was the most significant contribution to the conservation of biodiversity during this period (1994) at the regional level. Those SPAs were formed owing to the initiative of Kaliningrad State University scientists.

The main criteria for the selection of these territories were high biological diversity, unique landscapes, and a large number of rare species. However, already in 1998, the hunting lobby pressurized the start of a systematic destruction of the state nature reserve area as the basis for regional protection of biological diversity. In May 1998, the profile of three newly created nature reserves was changed from "complex (landscape)" to "zoological". Those SPAs, in fact, became hunting reserves with ensuing shrinking of environmental protection functions. The regional authorities thus prioritized environmental management over nature conservation (Dedkov \& Grishanov, 2014). The same decree rendered the Regulations for four previously created zoological reserves (1963 and 1976) invalid, and the Vistula Spit special protected area no longer appeared in the new general provision on state natural reserves. At the same time, the sanctuary mode extended for a period of 10 years (i.e. until 31.03.2004) was not cancelled. Thus, between 1998 and 2004, the conservation status of the Vistula Spit territory was legally questionable.

In 1999, the regional Department for the Protection, Control and Regulation of the Use of Hunting Animals proposed setting up, for a period of 10 years, a state biological (zoological) species reserve of regional significance in Slavsky District, with the aim to preserve the historically unique population of the Elk and to reproduce the number of species in the region. As a result, the reserve was established within the boundaries of Berezhkovskoe hunting farm. In fact, it was nothing but a raider capture of significant hunting grounds by stakeholders. A big positive step against this negative background was made with the resolution of 29.05.1999 No. 298 "On approving the list of wetlands 
(Peat Places) to be preserved in the intact state on the Kaliningrad Region territory", according to which 45 valuable wetlands were taken under protection.

At that time, the situation with the SPAs network on the territory of the Kaliningrad region was unsatisfactory. Research was carried out only on the territory of the „Vistula Spit State Nature Reserve (SNR)" (for the Russian part of the Vistula spit the name Baltic Spit is used) where Kaliningrad State University carried out detailed landscapegeobotanical studies and systematic ornithological observations (Gubareva, 1994; Grishanov, 1998, 2001). Resorts of federal significance (the SPAs of the Kaliningrad region included 2 resorts of federal significance from 2000 to 2013. They were Zelenogradsk and Svetlogorsk-Otradnoe according to the Federal Law of the Russian Federation "On specially protected territories") and natural monuments were almost not functioning as SPAs. The protection regime had been cancelled for the former complex nature reserves - the most valuable territories with the highest level of biological diversity. The only really functioning SPAs at the moment is the Curonian Spit Nature Park, which is small in area, quite specific in terms of biological diversity and is under a threat of a profound transformation of the main natural complexes owing to everincreasing recreational load (Dedkov \& Grishanov, 2014, Grishanov et al., 2016).

In 2004, the documents stipulating the conditions for SPAs formation and functioning expired, and were not formally extended for seven out of eight state natural reserves established by regional executive authorities in 1963, 1976, 1994. In fact, the regional system of SPAs aimed at maintaining biological diversity had been destroyed by that time (Dedkov \& Grishanov, 2014). In the same year, the regional government found it impossible to approve the Provision on the Vistula Spit state natural complex (landscape) - a reserve of regional significance - developed by the Administration of Natural Resources and Environmental Protection of the MNR of Russia for the Kaliningrad region. The refusal was explained by the fact that it would result in too many restrictions and prohibitions (A nature reserve was revoked of its status the day before yesterday. oopt.info. 02.04.2004). The protests of environmental organizations (Protected Baltic Spit interferes with government: A. Koroleva Ekozashchita's leader interview IA REGNUM. 29.03.2004), as well as the petition of the Baltiysk Council of Deputies to preserve the status of protected areas for the Vistula Spit (Elkina, 2004) were left unnoticed.

Lifting the SPAs status for all nature reserves took place without any scientific justification and environmental expertise required in such cases. The paradox of the situation is that the joint Russian-Swedish project for the development of the Nature Conservation Scheme for the Kaliningrad region had been completed by 2004. The final document contained the plan and scientific substantiation of SPA network development in the region; namely, it provided for the conservation status of the Vistula Spit as a state complex natural reserve of regional significance with the prospect of improving the conservation status in accordance with the level of its importance and priority. It was suggested that the Vistula Spit nature reserve be included in transboundary SPAs (Tsybin, 2004). Shortly after the nature reserves, the protected status of 45 wetlands was also revoked (regional administration decree No. 39 of 3.02.2005). The destruction of SPAs networks during the described period was due to another change of regional administration and unambiguous interests of private hunting and other organizations. Thus, according to the governor's decree of August 12, 2005, seven private companies received hunting grounds of 222 thousand ha ( $1 / 7$ of the region's territory) including the territories of the former nature reserves; no tendering was held for the use of wildlife objects. Only protests of scientific and cultural communities helped to cancel the notorious decree on hunting grounds. However, the status of nature reserves remained uncertain. There was no order to cancel the nature reserve regime, but the validity period 
had expired (Akimov, 2005; The Vice-Speaker of the Kaliningrad Duma accuses Governor Egorov of illegal transactions with state property. REGNUM. 09.09.2005).

An era of regulatory confusion in the field of nature conservation came with the appointment of the new governor from Moscow (Georgy Boos) and "non-locals" coming to power. Thus, in 2006, the new authorities recognized all SPAs of the region as valid and approved the "Concept the target regional program of ecological rehabilitation of the territory of the Kaliningrad region for 2006-2010" (No. 510 of 12.07.2006) (according to which the SPAs system of the region included the National Park "Curonian Spit", 2 resorts of federal significance, 8 state zoological reserves of regional significance, 59 natural monuments of regional significance and 45 specially protected wetlands (peat deposits). It was despite the fact that since March 2004 there had been neither resolutions on the extension of protection regime for 8 zoological reserves, nor resolutions on their elimination. Only three years later Governor's decrees (№ 7 from 04.02.2009 and №16 from 25.02.2009) put an end to all those regulatory inconsistencies. They cancelled the resolution establishing the Zapovedny zoological reserve and the notorious resolution № 351 from 18.05.1998 "On approval of the regulations concerning state natural reserves". The network of zoological reserves of the region was legally completely eliminated. As a result, in 2010 the Kaliningrad region officially had the Curonian spit National Park, two resorts of federal significance and 6o natural monuments of regional significance (Figure 2, Table 2).

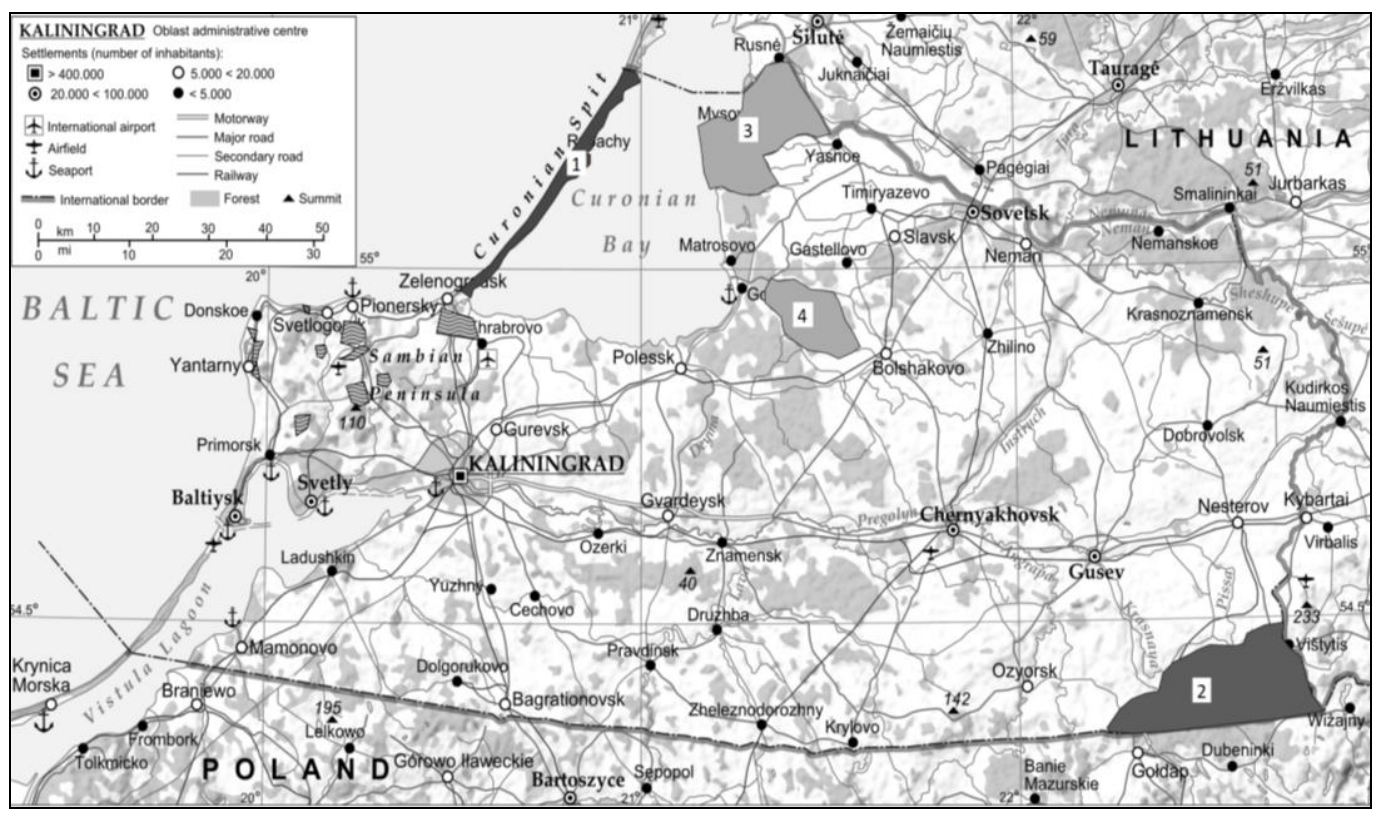

Figure 2. The scheme of SPAs of federal and regional importance of the Kaliningrad region for 2019 (without natural monuments)

Table 2. Legend to Figure 2

\begin{tabular}{|c|l|}
\hline 1 & The Curonian spit National Park \\
\hline 2 & The Vishtynetsky Natural Park \\
\hline 3 & Dyunny State nature reserve \\
\hline 4 & Gromovsky State nature reserve \\
\hline$\approx$ & $\begin{array}{l}\text { Strerves of the geological profile: Dunaevskoye, Mayskoye, Mozhaykino, Nadezhdinskoe 2, } \\
\text { Pionerskoye, Romanovskoye, Tikhorechenskoe, Filino, Shatrovskoye, Pokrovskoye }\end{array}$ \\
\hline
\end{tabular}




\section{CURRENT STATE OF THE SPAS NETWORK IN THE KALININGRAD REGION (2010-17)}

The environmental assessment of the project "Schemes of nature protection of the Kaliningrad region" revealed that of all the tasks planned in the "Concept of the target program of ecological improvement of the Kaliningrad region for the years 2006-2010" the only one implemented by 2010 was the publication of the Endangered Species List (The Red Data Book of the Kaliningrad region), developed by a team of Immanuel Kant Russian State University scientists with the participation of Kaliningrad State Technical University biologists (Dedkov \& Grishanov, 2010b). A "promising" development of a regional SPAs network can be traced in the so-called 2009 Forest plan of the Kaliningrad region. The plan includes only four projected (!) SPAs: the Baltic Spit, Dyunny, Gromovsky and Vishtynetsky compex nature reserves. Based on the Immanuel Kant Baltic Federal University team's research, three regional SPAs were organized in 2012 on the initiative of the Kaliningrad regional Government: the Vishtynetsky Natural Park, Dyunnny and Gromovsky complex reserves. Works were carried out within the framework of the first stage of the regional network set-up (natural framework nuclei) and their functioning optimization. Illegal amber mining and trafficking demanded protection status for amber deposits and related landscape elements in the region, which was done in May 2013 (9) and in June 2014 (1) through approval of 10 state natural reserves of a geological profile (Dunaevskoye, Mayskoye, Mozhaykino, Nadezhdinskoe 2, Pionerskoye, Romanovskoye, Tikhorechenskoe, Filino, Shatrovskoye and Pokrovskoye).

Therefore, creation of geological reserves is in fact a forced measure. After five years of these SPAs' existence, the situation with illegal mining has practically remained unchanged, obviously calling for tougher penalties. Thus, 83 specially protected areas of federal and regional importance have been created on the territory of the Kaliningrad Region during the entire post-war period. At present, 20 SPAs (nature reserves, nature monuments) have been reorganized, gone, or eliminated for various reasons. At the beginning of 2018 (Order of the Ministry of Natural Resources and Ecology of the Kaliningrad Region dated January 18, 2019 N18), the region's SPAs system included one national (Curonian Spit) and one natural park (Vishtynetsky), 12 state natural reserves of regional significance (two complex and 10 geological) and 50 natural monuments of regional importance (two hydrological and 48 dendrological). The possibility of creating federal-level protected areas (National Park Category) in the Kaliningrad Region is currently being discussed, the Baltic Spit and Vishtynetsky Natural Park being considered candidates for this status. (The Baltic Spit will become a specially protected natural area. gov39.ru. 10.07.2017; "The compromise suggested by the governor is impossible" rugrad.eu. 03.09.2019).

\section{CONCLUSION}

At all times, the SPAs system of a state or region represents a consensus of desires and needs between the government and society. The issues of continuity in the framework of changing political and socio-economic models on a certain territory also play an important and often unsurprising role. The issue of environmental protection is no exception here. Therefore, the state of environmental protection on the territory of the Kaliningrad region (pre-war and a current one) represents the role of the scientific and cultural community and the state's priorities in full: nature is either an object of protection or a resource for hunting or other foraging. The interests and needs of scientific and cultural community come second. It is from this angle that the question should be answered: is there a connection between the pre-war and post-war SPAs systems? Do the SPAs of the modern Kaliningrad region keep up the traditions and fulfil the tasks of pre-war protected areas? As mentioned above, the pre-war SPAs, German Elk Forest and Rominten Forest, performed the functions of hunting reserves at the highest 
state level in Germany. In the post-war period, they were mirrored by similar nature reserves - Kamensky, Maysko-Krasnopolyansky, etc. Soviet authorities failed to create a complex protected area of a raised bog similar to Zehlaubruch (it all ended poorly for Zehlaubruch after the war. A military training ground located to the south of the swamp causes irreparable damage by fires and destruction of vegetation). The Gromovsky and Dyunny nature reserves with valuable marsh complexes (Bolshoye Mokhovoye Marsh and part of Kozye Marsh) are comparable only in part, as they were created primarily as hunting reserves to preserve the elk population. This primary function again echoes that of pre-war protected areas, where the elk was also a key protected species (Elk Forest).

Only the Curonian Spit has retained its federal status because of its unique landscapes from the point of view of both German and Russian authorities. The Vyshtynetskiy Nature Park represents the reincarnation of the pre-war Rominten Forest whose creation, however, was fraught with certain difficulties. At the same time there are some interesting points. For example, the Sambian coast was not considered as a prospective special protected area during the Soviet period, but in 2010 it was included into the Protected Area List (The Red Data Book of the region) as a valuable ecosystem in need of special protection. The Vistula Spit did not enjoy a protection status before the war; then it was a nature reserve for 40 years (from 1963 to 2004); today, however, it is again viewed as a potential special protected area (The Baltic Spit will become a specially protected natural area. gov39.ru. 10.07.2017). Geological and geomorphological objects were also ignored during the Soviet period. The establishment of modern geological reserves is more likely a forced measure against illegal amber diggers than a scientifically based decision. The number of nature monuments is also incomparable: over 270 against 60. In general, it can be argued that there has been a qualitative and quantitative reduction of protected natural objects. However, at present, the studied region demonstrates a trend for strengthening the role of the scientific and cultural community in the selection of objects for the creation of protected areas of various levels.

\section{REFERENCES}

Akimov, V. (2005). Black Stork, White-backed Woodpecker..., Kaliningradskaya Pravda, 30 august, no. 161, p. 3. Bloech, H. (1980). Agriculture of East Prussia, Lueneburg, p. 24.

Boetticher, A. (1898). Instruction for the care and preservation of monuments in the province of East Prussia. Publishers Emil Rautenberg, Koenigsberg.

Brain, S. (2012). The Destruction of the Zapovedniki Revisited, Studies in the History of Biology, V. 4, no. 1, pp. 57-72. Brueckmann, R., (1923). Our Samland beach, p. 80.

Conwentz, H. (1904). The endangerment of natural monuments and suggestions for their conservation. Memorandum, presented to the Minister of Spiritual, Educational and Medical Affairs, Berlin.

Dedkov V. \& Grishanov, G. (2010a). The system of conservation areas as the basis for biodiversity preservation in the south-eastern Baltic, IKBFU's Vestnik. Ser. Natural and medical sciences, no. 7, pp. 8-13.

Dedkov, V. \& Grishanov, G. (2010b). The Red Book of the Kaliningrad region, Kaliningrad: I. Kant RSU, p. 334.

Dedkov V. \& Grishanov, G. (2014). Environmental studies in the southeastern Baltic region, In Environmental problems. Eurasian space. Moscow, MSU, pp. 302-317.

Elkina S. (2004). Deputies defended the reserve on the Baltic Spit, Yantarnyj Kraj, 3 June, p. 1.

Gams, H. \& Ruoff, S. (1929). History, structure and plant cover of the Zehlaubruch. In: Writings of the Phys.oekon. Society of Koenigsberg, B. 66, H.1, pp. 1-193.

Grenz, R. (1973). Labiau District. An East Prussian Homebook. Marburg/Lahn, p. 402.

Grishanov, G. (2001). Bird migration on the Vistula Spit of the Baltic Sea, Avian Ecology and behaviour, vol. 6, pp. 62-63.

Grishanov, G. (1998). The fauna of land vertebrates of the zoological wildlife sanctuary Wislin Spit» (Kaliningrad Region), Role of Protected Areas in Saving Biodiversity, Kaniv, pp. 176-177.

Grishanov, G. \& Grishanova Yu. (2016). Integration of the KOTR of the Kaliningrad region into the network of specially protected natural territories of regional significance, Inventory, monitoring and protection of key ornithological territories of Russia, no. 7. Mahachkala: Union of Birds of Russia, pp. 86-94.

Gubareva, I. (1994). Flora of the Vistula Spit, The Candidate Biological science abstract of dissertation: 03.00.05. St.-Petersburg, pp. 180. 
Jentzsch, A. (1878). The bogs of the province of Prussia. Koenigsberg in Pr. In: Writings of the Phys.-oekon. Society in Koenigsberg. pp. 89-131.

Jentzsch, A. (1900). Proof of the remarkable and to be protected trees, shrubs and erratic blocks in the province of East Prussia. In: Contributions to Prussia's natural history. Publishers Emil Rautenberg. Koenigsberg, p. 150.

Jessen, O. (1937). Village and dunes of Pillkoppen on the Curonian Spit, supplements to the reports of the Geographical Society of Rostock. Nr.8. Rostock, p. 27.

Schroetter, F. von \& Jaeck, C. (1978) Map of East Prussia with Prussian Lithuania and West Prussia with the Netz District, Wiesbaden, Steiner. - 25 Maps.

Kramer, H. (1990). Elk forest. Country, people, hunting. Hunting and cultural publishing, Sulzberg in Allgaeu, p. 356.

Kuchenyova. G. (1998). Study of the flora and vegetation of the Curonian Spit, Problems of study and conservation of the Curonian Spit, Kaliningrad, pp. 253-270.

Levchenkov, A. \& Ryabkova, O. (2012). Investigations of Zemland Peninsular Coasts in the Early XX Century, Geomorfologiya, no. 2, pp. 93-99.

Lohmeyer, H. (1961). Protected Territories of the German East. Yearbook of the Albertus-Universität zu Königsberg, Würzburg, pp. 306-311.

Lyubchenko, O. \& Liverovskaya, T. (2014). The history of the formation and current state of the network of protected areas in the northwest of the European part, Climate and Nature, no. 1(10), pp. 3-37.

Makeeva, E. (2017). Conservation policy of the USSR in the 1960-1980s: successes, failures and contradictions, In History and Archeology: materials of the IV International Scientific Conference - St-Petersburg, July 2017. St-Petersburg: Own publishing house, pp. 37-41.

Medvedev, V. (ed) (2016). Nature of the Kaliningrad region. Old trees. Kaliningrad: Istok, p. 104.

Medvedev, V. (ed) (2017) Nature of the Kaliningrad region: old parks and plants - regional monuments of nature. Kaliningrad: Istok, p. 104.

Poelking, H. (2012). East Prussia. Biography of a province. Be.bra Verlag, Berlin, p. 549.

Przypkowski, J. \& Jamski, P. (2005). The Photographer is here! People from the old East Prussia on historical photographs from the monument office in Koenigsberg. Warsaw: Institut of Art Polish Academy of Sciences, p. 173.

Schoenichen, W. (1926), Article to the conservation of natural monuments. The nature reserves of Prussia. Eleventh volum e. Berlin: Publishers Gebrueder Borntraeger, p. 333.

Schwill S., Strauss A., Napreenko M., Gusev W. \& Haberl A. (2010). 100 years Zehlau - climate relevance of a raised bog in Kaliningrad, Russia. Final report. Michael Succow Stiftung, p. 51.

Stiemer. (1875). Writings of of the Phys.-oekon. Society of Koenigsberg, 16th issues, Koenigsberg, pp. 7-20.

Tsybin, Y.A. (2004) Scheme of nature protection of the Kaliningrad Region. TENAX Media, Kaliningrad, p. 136 (in Russian).

Wagner, W. (2009). Cultur in rural East Prussia. History, manors and people in the District Gerdauen. In 2 volumes. Husum. p. 715 and p. 1384.

Wettengel, M. (1993). State and nature conservation 1906-1945. On the history of the State Agency for the Preservation of Natural Monuments in Prussia and the National Agency for Nature Conservation, Historical Journal, Vol. 257. pp. 355-592.

Volkova, I.I., Shaplygina, T.V. \& Bubnova, E.S. (2017). Specially Protected Natural Areas of the Kaliningrad Region. In: Gritsenko V.A., Sivkov V.V., Yurov A.V., Kostianoy A.G. (eds) Terrestrial and Inland Water Environment of the Kaliningrad Region. The Handbook of Environmental Chemistry, vol. 65. Springer, Cham, pp.481-494.

Zueva, A. (2017). Soul of the City, In Nature of the Kaliningrad region. Old parks and plants - regional monuments of nature. Kaliningrad: Istok, pp. 90-92.

*** Article to the conservation of natural monuments. The nature reserves of Prussia. Eleventh volume. (1926). Berlin, p. 333.

*** Angrapa Coast. The case of Gennady Razumovsky, In Artistic Publicistic Almanach, Special Issue. Kaliningrad: Yantarnyj Skaz, no. 2. 2006, p. 98.

*** A nature reserve was revoked of its status the day before yesterday. 02.04.2004. Retrieved from: http://oopt.info/news/o2a0404.html [Accessed: 26 March 2018].

*** Newsletter for nature conservation, no.1, 12th year's issues (1934), Berlin, p.37.

*** Protected Baltic Spit interferes with government: A. Koroleva Ekozashchita's leader interview IA REGNUM. 29.03.2004. Retrieved from: https://regnum.ru/news/238624.html [Accessed: 26 March 2018].

*** State archive of the Kaliningrad Region (SAKR), Fund P-380, Inventory 1, Case 8, Page 36-37.

*** State archive of the Kaliningrad Region (SAKR), Fund P-297, Inventory 7, Case 266, Page 26.

*** State archive of the Kaliningrad Region (SAKR), Fund P-380, Inventory 1, Case 3, Page 3.

*** State archive of the Kaliningrad Region (SAKR), Fund P-380, Inventory 1, Case 8, Page 12.

*** State archive of the Kaliningrad Region (SAKR), Fund P-380, Inventory 1, Case 3, Page 9-12.

*** State archive of the Kaliningrad Region (SAKR), Fund P-380, Inventory 1, Case 3, Page 7-8.

*** The Baltic Spit will become a specially protected natural area. The official portal of the Government of the Kaliningrad region. 10.07.2017. Retrieved from: https://gov39.ru/news/101/117445/ [Accessed: 30 March 2018].

*** The Vice-Speaker of the Kaliningrad Duma accuses Governor Yegorov of illegal transactions with state property. 09.09.2005 Retrieved from: https://regnum.ru/news/polit/510195.html [Accessed: 26 March 2018].

*** The compromise suggested by the governor is impossible. 03.09.2019Retrieved from: https://rugrad.eu/ interview/1136839/smi/ [Accessed: 04 September 2019].

Submitted:

19.06.2019
Revised:

02.03.2020
Accepted and published online 05.03.2020 